\title{
Effectiveness of a 'health promotional' intervention in enabling lay communities to change determinants of low birth weight
}

\author{
*Najith Duminda Galmangoda Guruge ${ }^{1}$, Samath D Dharmaratne ${ }^{2}$, M Wasantha Gunathunga ${ }^{3}$
}

Sri Lanka Journal of Child Health 2018; 47: 233-241

\begin{abstract}
Objective: To evaluate the effectiveness of a 'health promotional' intervention by lay people in changing determinants of low birth weight, when added to the existing package of antenatal care provision.
\end{abstract}

Method: A quasi-experimental study design was used. An intervention was carried out among 403 pregnant women and their partners. Intervention group (IG) was recruited from participants registered to routine field antenatal services in the Anuradhapura district. A comparison group (CG) of 403 pregnant women and their partners was recruited from an adjacent district. Both groups were recruited in the first trimester of pregnancy. The intervention was based on health promotion principles and used a model previously piloted in Sri Lanka. Data from the Child Health Development Record (CHDR) available at the health clinic were used to determine birth weights.

Results: Significant improvements were seen in the $\mathrm{IG}$, compared to the $\mathrm{CG}$, in the care given to the pregnant mothers by their families, and level of control over identified determinants of low birth weight $(\mathrm{LBW})$. The prevalence of LBW in the IG was $10.0 \%$ and in the CG $19.2 \%$. $\left(X^{2}=12.465\right.$; $\mathrm{p}<0.001)$ with an adjusted OR of 0.5 (95\% CI; 0.20.8 ) and mean birth weight in the IG $2987 \mathrm{~g}$ and in the CG 2772.4g $(\mathrm{t}=6.934 ; \mathrm{df}=726 ; \mathrm{p}<0.001)$.

\footnotetext{
${ }^{1}$ Senior Lecturer in Health Promotion, Faculty of Applied Sciences, Rajarata University of Sri Lanka, ${ }^{2}$ Associate Professor in Community Medicine, Faculty of Medicine, University of Peradeniya, Sri Lanka, ${ }^{3}$ Professor in Community Medicine, Head, Department of Community Medicine, Faculty of Medicine, University of Colombo, Sri Lanka

*Correspondence: dumindaguruge@gmail.com
}

(Received on 16 October 2017: Accepted after revision on 24 November 2017)

The authors declare that there are no conflicts of interest

Funding for the study was provided by the Higher Education for Twenty First Century (HETC) project, Ministry of Higher Education, Sri Lanka.

Open Access Article published under the Creative

Commons Attribution CC-BY (CC) (i)
Conclusion: The community centred health promotion intervention model was effective in enabling lay communities to change selected determinants of LBW and enabled lay communities to change determinants of LBW.

DOI: http://dx.doi.org/10.4038/sljch.v47i3.8546

(Keywords: Health promotional intervention, low birth weight determinants, community)

\section{Introduction}

Sri Lanka is recognized globally for having good health indicators despite the relatively weak status of its economic and developmental indicators ${ }^{1}$. However, indicators related to nutrition (e.g. prevalence of low birth weight, underweight, wasting and stunting) have shown the least improvement during the last decade ${ }^{2}$. A child's nutritional status is significantly influenced by birth weight. Therefore, addressing low birth weight (LBW) should improve the health of a population ${ }^{3}$. Current global prevalence of LBW is $15.5 \%{ }^{4}$. The antenatal period is an important stage in the life cycle in which interventions to improve birth weight can be implemented ${ }^{5,6}$. Antenatal period, the first 280 days of the first 1000 days of life, is an important stage in the life cycle in which interventions to improve birth weight can be implemented ${ }^{2,5,7}$. In a country in which $90 \%$ of pregnant mothers are registered for universally available antenatal care services provided free of charge by the government, this opportunity becomes more relevant than in other populations ${ }^{8}$. The LBW prevalence in Sri Lanka has stagnated around $16 \%-18 \%$ over the past 10 years ${ }^{9}$.

LBW has a wide range of determinants operating at individual, household, community and society levels, in different stages of the life cycle ${ }^{10-13}$. There are many modifiable factors related to dietary intake and care practices of the pregnant mother that can be effectively addressed during the antenatal period to prevent $\mathrm{LBW}^{5,14-16}$. As most of those determinants are dependent on the family, as well as the wider community, service provider oriented interventions will not be adequate to address LBW during this period. Complementary interventions can address the complex, interrelated household and community level determinants of LBW in the antenatal period. Global evidence suggests that programmes using an empowerment 
model of health promotion, involving communities in addressing determinants are effective in addressing complex problems and making sustainable changes ${ }^{17}$. There are no studies reported which have addressed such determinants in order to reduce LBW by lay people.

There is some local research on factors associated with LBW in Sri Lanka as well as in other countries and most of them have comparable findings to Kramer's study ${ }^{18-21}$. Anuranga and colleagues $^{22}$, in a review based on Ohlsson and Shah's synopsis and local DHS data analysis, suggest that food insecurity and poverty are the most important modifiable determinants for LBW. Therefore, it is recommended to address the issue of LBW if we are to effectively improve the health of a population ${ }^{3}$. The current study is a component of a multi-component study that aimed to improve birth weight in a rural district (Anuradhapura) in Sri Lanka.

\section{Objective}

The aim of this study was to evaluate the effectiveness of a 'health promotional' intervention in changing determinants of LBW by lay people, when added to the existing package of antenatal care provision.

\section{Method}

Study design: Quasi-experimental study design using mixed methods.

Study setting: Districts of Anuradhapura (intervention) and Polonnaruwa (comparison) in Sri Lanka. Anuradhapura district in the North Central Province of Sri Lanka was selected as the intervention area. Polonnaruwa district was purposively selected as the comparison area based on similarities in socio-demographic, cultural and economic characteristics and existing health care services.

Study population: All pregnant women registered in the $3^{\text {rd }}$ and $4^{\text {th }}$ quarters of the year 2012 in the selected antenatal clinics (ANCs) were included in the study. Pregnant women registering in the ANC after 12 weeks' period of amenorrhea (POA) and pregnant women with diagnosed medical conditions or co-morbidities at the time of registration were excluded from the study, because they get special care from the routine system.

Sample size for each group (IG and CG) was predetermined to be 403 , following the sample size calculation. This number was proportionately distributed to the three selected $\mathrm{MOH}$ areas in both $\mathrm{CG}$ and IG. Pregnant women who register to the selected clinics from starting date onwards (who matched the inclusion and exclusion criteria and gave consent for participation) were recruited consecutively until the sample size of each $\mathrm{MOH}$ area was completed. Since this procedure was used for selecting both the $\mathrm{CG}$ and $\mathrm{IG}$, samples size was 403 in each. Recruitment ceased as soon as the required number was reached.

Sampling procedure: A systematic sampling method was used to recruit participants from the selected districts. The primary sampling unit was the Medical Officer of Health (MOH) area and the secondary sampling unit was the ANC.

Development of study instruments: Study instruments were developed based on available literature and expert opinion. Two interviewer administered questionnaires were developed to obtain data on the following among pregnant women and their partners.

- Socio-demographic and economic characteristics: Civil status, age, ethnicity, educational level, occupation, monthly income, type of family and available extended family members at home, presence of husband at home, details of older children and whether the pregnancy was planned or not.

- Knowledge on growth and development of a fetus: Consequence of growth retardation, ways of monitoring and stimulation of intra-uterine development.

- Knowledge on LBW and its determinants: Knowledge on expected birth weight, expected maternal weight gain, determinants of LBW, maternal body mass index (BMI) and nutrition (adequacy, quality, available food types)

- Care of pregnant mothers - Perceptions on adequacy of rest, nutritional intake and support from the partner

Recruitment and training of research assistants: Twelve research assistants with either a degree or a diploma in health promotion (from Rajarata University of Sri Lanka) were recruited for data collection. A two day workshop was conducted to train them.

Ethics approval and consent to participate: Ethical clearance was obtained from the Ethics Review Committee of Faculty of Medicine, University of Colombo and administrative clearance was obtained from the Regional Director of Health Services of Anuradhapura District.

Pre-intervention assessment: The data for preintervention assessment was collected at or around 
the first clinic visit, by the trained research assistants.

Collecting data from pregnant women: The interviews were conducted on the same day by trained research assistants after obtaining informed written consent.

Collecting data from their partners: If the partners were available at the first clinic visit, they were interviewed on the same day, after obtaining informed written consent. If they were not available on that day, appointments were made to interview them later. Partners were met at their households on a pre-agreed date and time, within two weeks of the interview of the pregnant woman.

\section{Process}

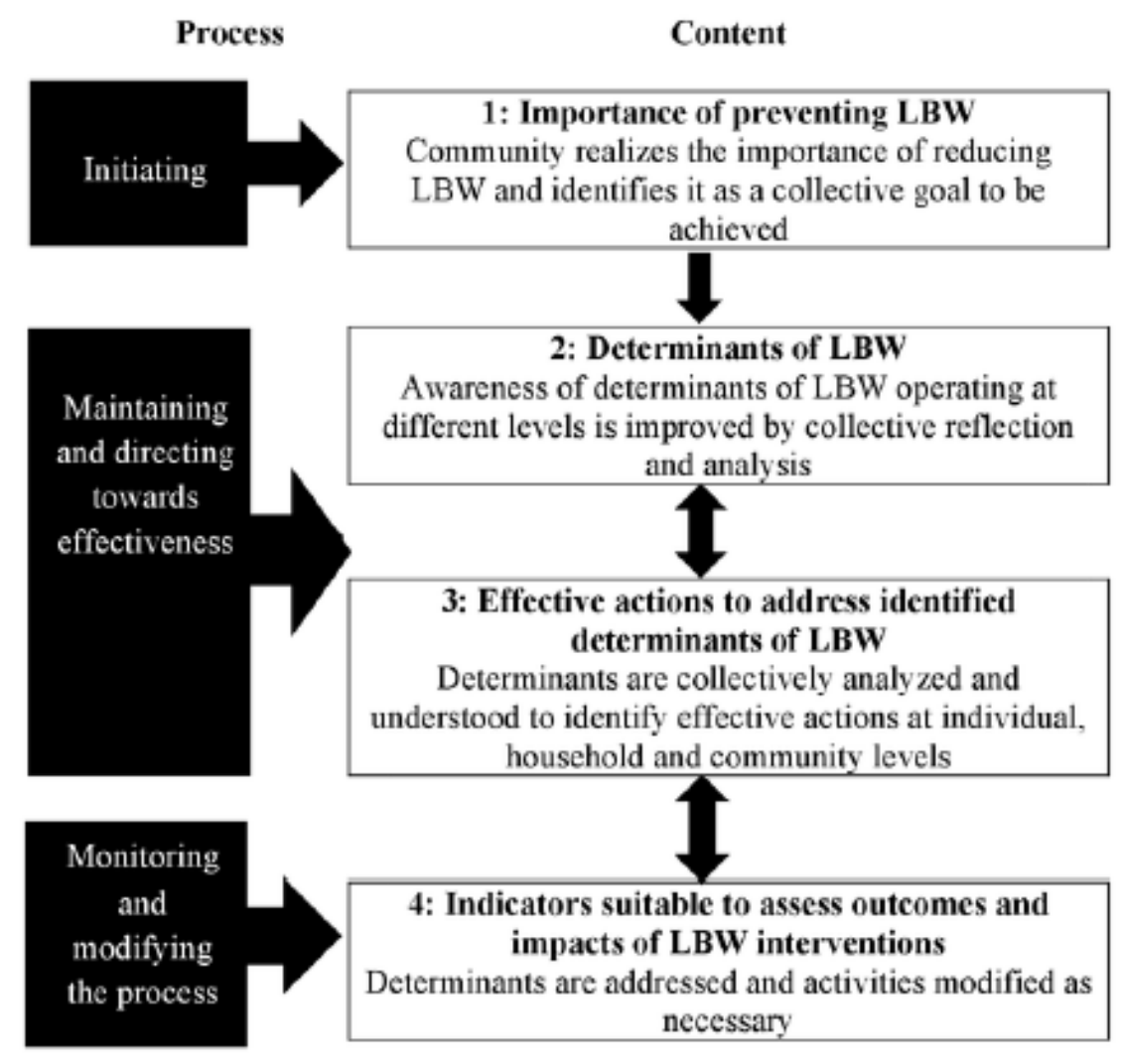

Extracting data to assess fetal and maternal outcomes: The data were extracted from the pregnancy record parts $\mathrm{A}$ and $\mathrm{B}$. When data were incomplete in any of the records mentioned above, pregnant mother's register available with the relevant Public Health Midwife (PHM) was used to record missing information e.g. BMI, POA at registration, expected date of delivery (EDD) $\}$, were re-checked and data from different records compared for accuracy, whenever possible.

Development and implementation of the intervention

The conceptual framework for the process of intervention was based on a community centred health promotion intervention model. The adopted model (Figure 1) consisted of two integrated components; content and the process.

Figure 1: Conceptual framework for the process

Initiating: Identifying prevention of $L B W$ as a collective goal

Even though the goal of reducing the prevalence of LBW was predetermined by the researcher, it should be identified as a goal by the community as well. Thus, according to health promotion principles, a positive or a non-problem based approach was used to advocate to the community the importance of adequate weight at birth.

\section{Maintaining and directing toward effectiveness}

$i$. Understanding determinants
In this step, participants were stimulated to engage in a collective reflection on "factors that influence birth weight". The researcher then built on the list of determinants formulated by the community, improving their awareness on the wide range of factors operating at different levels (individual, household, community and society) and different stages of life cycle (pre-pregnancy and pregnancy). Then the participants were stimulated to collectively reflect on the identified list of determinants and prioritize them based on their importance and feasibility for modification. 
ii. Identifying effective actions

This was done by collectively analysing the identified determinants to identify underlying determinants that should be addressed. The analysis started on the first session with a few selected determinants collectively agreed upon, and was then scaled up to incorporate the complete list in subsequent sessions. Principal researcher facilitated discussions and provided technical inputs in deciding the actions (Table 1).

Table 1: Actions identified and implemented by the community to address the identified determinants of low birth weight

\begin{tabular}{|c|c|c|}
\hline No. & Determinant & Actions \\
\hline 1 & Maternal nutrition & $\begin{array}{ll}\text { - } & \text { Nutrition diary/nutrition calendar } \\
\text { - } & \text { Homemade multiple micronutrient supplement ("Vibhaga Pohora") } \\
\text { - } & \text { Model menus with cheap, locally available foods } \\
\text { - } & \text { Food sharing } \\
\text { - } & \text { Home gardening }\end{array}$ \\
\hline 2 & Partner's support & $\begin{array}{ll}\text { - } & \text { Participation calendar } \\
\text { - } & \text { Happiness calendar } \\
\text { - } & \text { Pregnant mother's room } \\
\text { - } & \text { Interactions with nature (bird watching, stars etc.) } \\
\end{array}$ \\
\hline 3 & $\begin{array}{l}\text { Maternal rest/ Work } \\
\text { load }\end{array}$ & $\begin{array}{ll}\text { - } & \text { Participation calendar } \\
\text { - } & \text { Happiness calendar } \\
\text { - } & \text { Collective feeding } \\
\text { - } & \text { Collective 'play houses' } \\
\text { - } & \text { Interactions with nature (bird watching, stars etc.) }\end{array}$ \\
\hline 4 & Maternal happiness & $\begin{array}{ll}\text { - } & \text { Happiness calendar } \\
\text { - } & \text { Pregnant mother's room } \\
\text { - } & \text { Participation calendar } \\
\text { - } & \text { Stimulation calendar } \\
\text { - } & \text { Listening to lullabies } \\
\text { - } & \text { Interactions with nature (bird watching, stars etc.) }\end{array}$ \\
\hline 5 & $\begin{array}{l}\text { Care from other family } \\
\text { members/neighbors }\end{array}$ & $\begin{array}{l}\text { - } \quad \text { Participation calendar } \\
\text { - } \quad \text { Nutrition calendar } \\
\text { - } \quad \text { Food sharing } \\
\text { - Homemade multiple micronutrient supplement } \\
\text { - } \quad \text { Pregnant mother's room } \\
\text { - Collective feeding } \\
\text { - } \quad \text { Collective 'play houses' } \\
\text { - Interactions with nature (bird watching, stars etc.) }\end{array}$ \\
\hline 6 & Indoor air pollution & $\begin{array}{ll}\text { - } & \text { Smoke free homes } \\
\text { - } & \text { Remodeling/restructuring kitchens } \\
\text { - } & \text { 'Pleasant house' (Siriyavantha nivasa) }\end{array}$ \\
\hline 7 & $\begin{array}{l}\text { Exposure to tobacco } \\
\text { smoke }\end{array}$ & $\begin{array}{ll}\text { - } & \text { 'Smoke (Tobacco) free homes' } \\
\text { - } & \text { Motivating husbands to quit smoking } \\
\text { - } & \text { Motivating local vendors to stop selling cigarettes }\end{array}$ \\
\hline 8 & Poverty & $\begin{array}{ll}\text { - } & \text { Expenditure diary } \\
\text { - } & \text { Reducing tobacco use } \\
\text { - } & \text { Reducing alcohol use } \\
\text { - } & \text { Reducing consumption of processed foods }\end{array}$ \\
\hline 9 & Maternal infections & - $\quad$ 'Pleasant house' (Siriyavantha nivasa) \\
\hline
\end{tabular}

\section{Monitoring and modifying the process}

Collective actions agreed upon were implemented at individual, household and community level, coordinated by the Neighbourhood Action Committees. The implementation of actions differed from setting to setting and within the setting based on the participants' capacities and enthusiasm for involvement. The order of implementation also differed at all levels (individual, household, community) based on the identification and understanding of the determinants by respective categories. Participants, Neighbourhood Action Committees and the communities were facilitated to select the actions and mechanisms and order of implementation, based on their capacities and enthusiasm perceived 
by the researcher. Throughout the intervention process, special attention was paid to the recognized risk factors for delivering LBW babies. They were then guided to explore how to deal with these, giving special attention to pregnant women who may have higher risk. This understanding rippled through the community, enhancing the supportiveness of the respective environments.

\section{Post-intervention assessment}

Phase I was conducted using the same methods described in the pre-intervention assessment. Phase II was conducted to assess the care received by the newborn and the post-partum woman using an interviewer administered questionnaire. It was used to assess the care received by the postpartum woman. It contained questions to assess the following.

- Identification data

- Division of household chores

- Decision making in the household

\section{Data collection}

The data was collected at or around 28 days in the postpartum period by the trained research assistants who visited the households in pre-arranged dates. Data extraction sheet was used to obtain information to assess maternal and fetal outcomes and related factors. The data were extracted from the pregnancy record parts $\mathrm{A}$ and $\mathrm{B}$ and (CHDR) parts $\mathrm{A}$ and $\mathrm{B}$ (post-delivery data) maintained at the clinic.

\section{Data analysis}

Data were entered using the Microsoft Excel Office package and was analyzed using SPSS version 22. Where numbers in questionnaire results were compared, Chi Square and Fisher's Exact Test were used. Pre- and post- intervention comparison of proportions, of correct responses within the group, was done using MacNemar's Chi Square statistic.

Knowledge scores were determined by totaling the number of correct responses made by each participant and the pre- and post- interventional mean scores were compared between the groups using Student's t-test for independent samples or Mann Whitney U Test, depending on the normality of the distribution. Comparison within the groups was done using Paired t-test and Wilcoxon Signed Rank Test, based on the normality of the distribution.

\section{Results}

Response rate: Four hundred and three participants were recruited from the two areas. Some were excluded from the analysis due to second trimester miscarriages and withdrawal of consent. Final response rates were 98.5\% $(n=397)$ and $96.0 \%$ $(n=387)$ from the IG and the CG respectively.

Knowledge among pregnant women: Although knowledge items showed significant increase on some items, they are not presented in this paper due to considerations of length.

Care of the pregnant women: Pregnant women perceived an increase of support given by the partner during pregnancy. The significant difference between groups is in 'perceived rest'. IG pregnant women reported a higher mean score than CG pregnant women on 'perceived rest' (IG; Mean=4.7, $\mathrm{SD}=1.2$ ) Mothers in IG felt that the rest they had was significantly more at post-assessment, while those in the $\mathrm{CG}$ perceived rest had declined in the post intervention assessment (Table 2).

Table 2: Comparison of perceived care during pregnancy in the intervention group (IG) and comparison group (CG) in pre-and post-assessments - woman's perspective

\begin{tabular}{|c|c|c|c|c|c|}
\hline \multirow[b]{2}{*}{ Indicator of support } & \multicolumn{2}{|c|}{ IG $(n=347)$} & \multicolumn{2}{|c|}{ CG $(n=339)$} & \multirow[b]{2}{*}{$\begin{array}{l}p \text { between } \\
\text { groups** }\end{array}$} \\
\hline & $\begin{array}{c}\text { Pre } \\
\text { Mean (SD) }\end{array}$ & $\begin{array}{c}\text { Post } \\
\text { Mean (SD) }\end{array}$ & $\begin{array}{c}\text { Pre } \\
\text { Mean (SD) }\end{array}$ & $\begin{array}{c}\text { Post } \\
\text { Mean (SD) }\end{array}$ & \\
\hline \multirow{2}{*}{$\begin{array}{l}\text { Perceived support from the } \\
\text { partner }\end{array}$} & $1.9(1.0)$ & $2.8(0.5)$ & $1.7(1.1)$ & $2.7(0.5)$ & \multirow{2}{*}{$\begin{array}{l}\text { pre } p=0.066 \\
\text { post } p=0.148\end{array}$} \\
\hline & \multicolumn{2}{|c|}{$\mathrm{p}<0.001^{*}$} & \multicolumn{2}{|c|}{$\mathrm{p}<0.001 *$} & \\
\hline \multirow[t]{2}{*}{ Perceived adequacy of diet } & $4.2(1.3)$ & $4.4(1.5)$ & $4.6(1.3)$ & $4.3(1.1)$ & \multirow{2}{*}{$\begin{array}{l}\text { pre } p=0.793 \\
\text { post } p=0.811\end{array}$} \\
\hline & \multicolumn{2}{|c|}{$\mathrm{p}=0.832 *$} & \multicolumn{2}{|c|}{$\mathrm{p}=0.091^{*}$} & \\
\hline \multirow[t]{2}{*}{ Perceived rest } & $3.4(1.1)$ & $4.7(1.2)$ & $3.6(1.0)$ & $2.4(1.1)$ & \multirow{2}{*}{$\begin{array}{l}\text { pre } \mathrm{p}=0.238 \\
\text { post } \mathrm{p}<0.001\end{array}$} \\
\hline & \multicolumn{2}{|c|}{$\mathrm{p}<0.001^{*}$} & \multicolumn{2}{|c|}{$\mathrm{p}=0.021 *$} & \\
\hline
\end{tabular}

*Paired t test; **Student's independent sample t test $(d f=684)$, equal variances not assumed

Results of perceived care during pregnancy as reported by the partner are described in Table 3 . Partners of pregnant women in IG reported at the post-assessment that they provided significantly more support to her while no such difference was reported in CG partners (Table 3). Despite this, IG partners, unlike $\mathrm{CG}$, were not satisfied that they had successfully provided the pregnant mother with adequate rest. Partners in IG also reported a perceived increase (M2-M1 $=0.9 ; \mathrm{p}=0.002)$ in the adequacy of diet at the post intervention $(\mathrm{M}=4.8$, $\mathrm{SD}=1.1)$ 
Table 3: Comparison of perceived care during pregnancy in the intervention group (IG) and comparison group (CG) in pre-and post-assessments - partner's perspective

\begin{tabular}{|c|c|c|c|c|c|}
\hline \multirow[b]{2}{*}{ Indicator of support } & \multicolumn{2}{|c|}{ IG $(n=323)$} & \multicolumn{2}{|c|}{ CG $(n=293)$} & \multirow[b]{2}{*}{$\begin{array}{l}p \text { between } \\
\text { groups** }\end{array}$} \\
\hline & $\begin{array}{c}\text { Pre } \\
\text { Mean (SD) }\end{array}$ & $\begin{array}{c}\text { Post } \\
\text { Mean (SD) }\end{array}$ & $\begin{array}{c}\text { Pre } \\
\text { Mean (SD) }\end{array}$ & $\begin{array}{c}\text { Post } \\
\text { Mean (SD) }\end{array}$ & \\
\hline \multirow[t]{2}{*}{ Perceived support given } & $3.8(1.2)$ & $4.8(0.8)$ & $3.6(1.1)$ & $4.3(1.0)$ & \multirow{2}{*}{$\begin{array}{l}\text { pre } \mathrm{p}=0.025 \\
\text { post } \mathrm{p}<0.001\end{array}$} \\
\hline & \multicolumn{2}{|c|}{$\mathrm{p}<0.001^{*}$} & \multicolumn{2}{|c|}{$\mathrm{p}<0.001^{*}$} & \\
\hline \multirow{2}{*}{$\begin{array}{l}\text { Perceived adequacy of diet } \\
\text { of the pregnant woman }\end{array}$} & $4.1(1.6)$ & $4.8(1.1)$ & $4.2(1.3)$ & $4.5(1.4)$ & \multirow{2}{*}{$\begin{array}{l}\text { pre } p=0.145 \\
\text { post } p=0.012\end{array}$} \\
\hline & \multicolumn{2}{|c|}{$\mathrm{p}=0.002^{*}$} & \multicolumn{2}{|c|}{$\mathrm{p}=0.351^{*}$} & \\
\hline \multirow{2}{*}{$\begin{array}{l}\text { Perceived rest of the } \\
\text { pregnant woman }\end{array}$} & $4.8(1.1)$ & $4.1(0.6)$ & $4.8(1.0)$ & $4.7(1.1)$ & \multirow{2}{*}{$\begin{array}{l}\text { pre } \mathrm{p}=0.938 \\
\text { post } \mathrm{p}<0.001\end{array}$} \\
\hline & \multicolumn{2}{|c|}{$\mathrm{p}=0.002 *$} & \multicolumn{2}{|c|}{$\mathrm{p}=0.984^{*}$} & \\
\hline
\end{tabular}

*Paired t test; **Student's independent sample t test $(d f=684)$, equal variances not assumed

Partners of pregnant women in IG reported at the post-assessment that they provided significantly more support to them while no such difference was reported by CG partners (Table 3). Despite this, IG partners, unlike $C G$, were not satisfied that they had successfully provided the pregnant mother with adequate rest. This probably reflects an increased sensitivity to the needs of the pregnant mother, on the part of the husbands in the intervention group.

\section{Perceived support}

Perceived support in household chores, spending more time at home and participating in the ANC increased significantly in IG compared to the $\mathrm{CG}$ (Table 4). Mean scores in IG improved significantly in all indicators $(p<0.001)$. A highest increase was seen in helping in household chores (4.1-2.9) and in participating at ANC visits (2.0$0.8)$.

Table 4: Comparison of partners' support in different aspects of care in the intervention group (IG) and comparison group (CG) in pre-and post-assessments - woman's perspective

\begin{tabular}{|c|c|c|c|c|c|}
\hline \multirow[t]{2}{*}{ Indicator of support } & \multicolumn{2}{|c|}{ IG $(n=347)$} & \multicolumn{2}{|c|}{ CG $(n=339)$} & \multirow[b]{2}{*}{$\begin{array}{l}p \text { between } \\
\text { groups** }\end{array}$} \\
\hline & $\begin{array}{c}\text { Pre } \\
\text { Mean (SD) }\end{array}$ & $\begin{array}{c}\text { Post } \\
\text { Mean (SD) }\end{array}$ & $\begin{array}{c}\text { Pre } \\
\text { Mean (SD) }\end{array}$ & $\begin{array}{c}\text { Post } \\
\text { Mean (SD) }\end{array}$ & \\
\hline \multirow{2}{*}{$\begin{array}{l}\text { Helping in household } \\
\text { chores }\end{array}$} & $2.9(1.7)$ & $4.1(1.3)$ & $2.4(1.4)$ & $3.6(1.5)$ & \multirow{2}{*}{$\begin{array}{l}\text { pre } p=0.003 \\
\text { post } p<0.001\end{array}$} \\
\hline & \multicolumn{2}{|c|}{$\mathrm{p}<0.001^{*}$} & \multicolumn{2}{|c|}{$\mathrm{p}<0.001^{*}$} & \\
\hline \multirow[t]{2}{*}{$\begin{array}{l}\text { Spending more time at } \\
\text { home }\end{array}$} & $1.6(1.3)$ & $2.5(1.5)$ & $1.2(1.3)$ & $1.8(1.1)$ & $\begin{array}{l}\text { pre } p=0.013 \\
\text { post } p<0.001\end{array}$ \\
\hline & \multicolumn{2}{|c|}{$\mathrm{p}<0.001^{*}$} & \multicolumn{2}{|c|}{$\mathrm{p}<0.001^{*}$} & \\
\hline \multirow[t]{2}{*}{ Participating to the ANC } & $0.8(1.1)$ & $2.0(1.6)$ & $0.5(1.0)$ & $1.3(1.1)$ & \multirow{2}{*}{$\begin{array}{l}\text { pre } p=0.001 \\
\text { post } p<0.001\end{array}$} \\
\hline & \multicolumn{2}{|c|}{$\mathrm{p}<0.001^{*}$} & \multicolumn{2}{|c|}{$\mathrm{p}<0.001 *$} & \\
\hline
\end{tabular}

*Paired t test; **Student's independent sample t test $(d f=684)$, equal variances not assumed

\section{Involvement in decision making}

The part played by the pregnant woman and the partner in decision making are shown in Table 5. Proportions of decisions made alone (by the woman or the partner), rather than jointly, in the IG were significantly lower compared to the $\mathrm{CG}$ in all indicators other than for 'where to seek medical care' (Table 5).

\section{Tobacco and alcohol use}

Results of tobacco and alcohol use of partners are described in Table 6. There was a statistically significant reduction in mean number of cigarettes smoked per day in the intervention group $(\mathrm{p}<0.001)$.

Birth weight

The prevalence of low birth weight was lower in the IG (Table 7)

\section{Mean birth weight}

Mean birth weight reported in the IG (Mean=2987.3g; SD=427.5g) was 215g higher than the mean birth weight reported in the $\mathrm{CG}$ (Mean=2772.4; $\mathrm{SD}=408.0$ ) as shown in Table 8. 
Table 5: Comparison of involvement of pregnant women in decision making in intervention group (IG) and comparison group (CG)

\begin{tabular}{|c|c|c|c|c|}
\hline No. & $\begin{array}{c}\text { Decisions made during } \\
\text { pregnancy }\end{array}$ & $\begin{array}{c}\text { IG }(n=330) \\
\text { No. }(\%)\end{array}$ & $\begin{array}{c}\text { CG }(n=308) \\
\text { No. }(\%)\end{array}$ & $\begin{array}{c}\text { Chi square } \mathrm{df}=\mathbf{2} \\
p \text { value }\end{array}$ \\
\hline 1 & $\begin{array}{l}\text { Deciding when to seek medical care } \\
\text { Pregnant woman alone } \\
\text { Partner or another person alone } e^{\#} \\
\text { Jointly with partner or someone else }{ }^{\#}\end{array}$ & $\begin{array}{c}57(17.3) \\
61(18.5) \\
212(64.2) \\
\end{array}$ & $\begin{array}{c}104(33.8) \\
50(16.2) \\
154(50.0)\end{array}$ & $\begin{array}{c}X^{2}=21.474 \\
\mathrm{p}<0.001\end{array}$ \\
\hline 2 & $\begin{array}{l}\text { Deciding where to seek medical care } \\
\text { Pregnant woman alone } \\
\text { Partner or another person alone } e^{\#} \\
\text { Jointly with partner or someone else }\end{array}$ & $\begin{array}{c}58(17.6) \\
63(19.1) \\
209(63.3) \\
\end{array}$ & $\begin{array}{l}69(22.4) \\
48(15.6) \\
191(62.0) \\
\end{array}$ & $\begin{aligned} X^{2} & =2.868 \\
p & <0.001\end{aligned}$ \\
\hline 3 & $\begin{array}{l}\text { Deciding the amount spent on food } \\
\text { Pregnant woman alone } \\
\text { Partner or another person alone }{ }^{\#} \\
\text { Jointly with partner or someone else }\end{array}$ & $\begin{array}{l}48(14.5) \\
117(35.5) \\
165(50.0) \\
\end{array}$ & $\begin{array}{l}50(16.2) \\
144(46.8) \\
114(37.0) \\
\end{array}$ & $\begin{aligned} X^{2} & =10.256 \\
\mathrm{p} & =0.006\end{aligned}$ \\
\hline 4 & $\begin{array}{l}\text { Deciding which items to buy for the newborn } \\
\text { Pregnant woman alone } \\
\text { Partner or another person alone } \\
\text { Jointly with partner or someone else }\end{array}$ & $\begin{array}{c}95(28.8) \\
34(10.3) \\
201(60.9) \\
\end{array}$ & $\begin{array}{l}119(38.6) \\
42(13.6) \\
147(47.7)\end{array}$ & $\begin{aligned} X^{2} & =10.559 \\
\mathrm{p} & =0.005\end{aligned}$ \\
\hline 5 & $\begin{array}{l}\text { Deciding which items to buy for the delivery } \\
\text { Pregnant woman alone } \\
\text { Partner or another person alone }{ }^{\#} \\
\text { Jointly with partner or someone else }\end{array}$ & $\begin{array}{c}119(36.1) \\
19(05.8) \\
192(58.2) \\
\end{array}$ & $\begin{array}{l}176(57.1) \\
22(07.1) \\
110(35.7) \\
\end{array}$ & $\begin{aligned} X^{2} & =30.603 \\
p & <0.001\end{aligned}$ \\
\hline 6 & $\begin{array}{l}\text { Deciding where to go for the delivery } \\
\text { Pregnant woman alone } \\
\text { Partner or another person alone* } \\
\text { Jointly with partner or someone else }\end{array}$ & $\begin{array}{l}43(13.0) \\
100(30.3) \\
187(56.7)\end{array}$ & $\begin{array}{l}89(28.9) \\
84(27.3) \\
135(43.8)\end{array}$ & $\begin{aligned} X^{2} & =22.956 \\
\mathrm{p} & <0.001\end{aligned}$ \\
\hline
\end{tabular}

\#Involvement of someone else other than the partner was less than $3 \%$ in all indicators in both groups *66 (20.0\%) in the IGand 52(17\%) in the CG mentioned the decision was solely taken by another person

Table 6: Comparison of partners' tobacco and alcohol use in the intervention group (IG) and comparison group (CG) in the pre and post assessments

\begin{tabular}{|c|c|c|c|c|c|}
\hline \multirow[t]{2}{*}{ Prevalence of use } & \multicolumn{2}{|c|}{ IG $(n=323)$} & \multicolumn{2}{|c|}{ CG $(n=293)$} & \multirow{2}{*}{$\begin{array}{c}p \text { between } \\
\text { groups* }\end{array}$} \\
\hline & Pre & Post & Pre & Post & \\
\hline \multirow{3}{*}{$\begin{array}{l}\text { Tobacco use } \\
\text { Current smokers No. (\%) }\end{array}$} & & & & & pre $p=0.776$ \\
\hline & $79(24.5)$ & $71(22.0)$ & $69(23.5)$ & $77(26.3)$ & post $p=0.231$ \\
\hline & \multicolumn{2}{|c|}{$\mathrm{p}=0.332$} & \multicolumn{2}{|c|}{$\mathrm{p}=1.000$} & \\
\hline \multirow[t]{2}{*}{$\begin{array}{l}\text { No per day (only among daily } \\
\text { smokers) Mean (SD) }\end{array}$} & $5.2(4.7)$ & $2.8(2.5)$ & $3.8(3.7)$ & $4.1(5.4)$ & $\begin{array}{c}\text { pre } \mathrm{p}=0.247 * * \\
\text { post } \\
\mathrm{p}=0.453^{* *}\end{array}$ \\
\hline & \multicolumn{2}{|c|}{$\mathrm{p}<0.001 * * *$} & \multicolumn{2}{|c|}{$\mathrm{p}=0.427 * * *$} & \\
\hline \multirow[t]{2}{*}{$\begin{array}{l}\text { Alcohol use } \\
\text { Current drinkers No. (\%) }\end{array}$} & $198(61.3)$ & $192(59.4)$ & $180(61.4)$ & $181(61.8)$ & $\begin{array}{l}\text { pre } p=0.997 \\
\text { post } p=0.642\end{array}$ \\
\hline & \multicolumn{2}{|c|}{$\mathrm{p}=0.839$} & \multicolumn{2}{|c|}{$\mathrm{p}=0.454$} & \multirow{6}{*}{$\begin{array}{l}\text { pre } p=0.034 \\
\text { post } p=0.642\end{array}$} \\
\hline Frequency of use & $n=198$ & $n=192$ & $n=180$ & $n=181$ & \\
\hline Daily No. (\%) & $0(0.0)$ & $0(0.0)$ & $01(0.6)$ & $01(0.6)$ & \\
\hline More than 3 times/week No. (\%) & $01(0.5)$ & $03(1.6)$ & $01(0.6)$ & $01(0.6)$ & \\
\hline More than 3 times/month No. (\%) & $51(25.8)$ & $40(20.8)$ & $23(12.8)$ & $29(16.0)$ & \\
\hline Once a month or less & $146(73.7)$ & $149((77.6)$ & $155(86.1)$ & $150(82.9)$ & \\
\hline
\end{tabular}

*Chi Square test $(d f=1) ; * *$ Independent T test, ***Paired T test 
Table 7: Comparison of prevalence of low birth weight in the intervention group (IG) and comparison group (CG)

\begin{tabular}{|l|c|c|c|}
\hline \multicolumn{1}{|c|}{ Characteristic } & IG $(\boldsymbol{n}=\mathbf{3 7 0})$ & CG $(\boldsymbol{N}=\mathbf{3 5 9})$ & Chi square, $\mathbf{d f}=\mathbf{1}, \boldsymbol{p}$ value \\
\hline Prevalence of LBW No. (\%) & $37(10.0)$ & $69(19.2)$ & $X^{2}=12.465 ; \mathrm{p}<0.001$ \\
\hline Crude OR [95\%CI] & \multicolumn{2}{|c|}{$0.5[0.3,0.7]$} & \\
\hline Adjusted for short stature & \multicolumn{2}{|c|}{$0.5[0.3,0.8]$} & \\
\hline
\end{tabular}

Table 8: Comparison of mean birth weight in the intervention group (IG) and comparison group (CG)

\begin{tabular}{|c|c|c|c|}
\hline Characteristic & IG $(\boldsymbol{n}=\mathbf{3 7 0})$ & $\mathbf{C G}(\mathbf{N}=\mathbf{3 5 9})$ & t-test, $\mathbf{p}$ value, $\mathrm{df}=726$ \\
\hline Mean birth weight Mean (SD) & $2987.3 \mathrm{~g}(427.5 \mathrm{~g})$ & $2772.4 \mathrm{~g}(408.0 \mathrm{~g})$ & $\mathrm{t}=6.934, \mathrm{p}<0.001$ \\
\hline
\end{tabular}

\section{Discussion}

The present study is unique in that intervention was directed at lay people. There are no published studies on the effectiveness of community based interventions for changing determinants of LBW. Quantitative findings revealed participants of IG received a higher quality of care and had a higher level of control over the determinants of LBW, compared to the CG. The intervention proved to be effective in provision of additional care at household and community levels and in providing the pregnant woman a higher level of control over the determinants of LBW. These determinants are probably not influenced by the routine health delivery system. The strategy used in this intervention allowed the intervention to be delivered to over four hundred mothers in several locations with relatively small investment of researcher's time per mother. Measuring the inputs was not part of this study but should be included in any future replication. The significantly lower prevalence of LBW and the higher mean birth weight seen in the IG supports the idea that the issues addressed were indeed determinants of LBW. But evidence of impact on birth weight is only suggestive, as pregnant women were not individually matched or randomly assigned between the two groups.

Higher birth weight in the IG suggests that the factors addressed do play a role in determining birth weight. The results demonstrate that significant changes in these determinants were achieved through the intervention. These findings suggest that the intervention tested is a potentially beneficial supplement to the package of antenatal interventions currently carried out by the field health services of the Ministry of Health. Present interventions do not provide for an active role for pregnant women and communities in formulating strategies to address the determinants of LBW that were targeted in this intervention.

One difficulty in health promotion research is encountered in this study too - namely, that the pre-assessment tools cannot anticipate the factors that communities will choose to address during the intervention process. Pre-prepared tools have to be used to measure changes at post assessment too - although they do not cover the entire range of determinants that are addressed during the intervention. Different methods need to be developed to measure outcomes and impact of health promotion interventions comprehensively.

\section{Conclusions}

The findings provide support for the effectiveness of a community centred health promotion intervention model, where lay communities are trained to identify and address determinants of LBW in their communities, using their own resources. This study demonstrated the value of encouraging lay people to take control of analysing and addressing determinants and measuring results using sensitive indicators. The technical inputs required to initiate, guide and sustain the process was relatively small.

\section{Acknowledgements}

We thank Dr. K M N Perera for data coding, analyzing and helping. We also acknowledge, Dr. Sansfica Marlyn Young for assistance and support. Research assistants, the local health authorities are acknowledged for their support in different ways. We are most grateful to the families and communities who participated in the study.

\section{References}

1. World Health Organization. World Health Statistics 2015. Geneva. World Health Organization 2016.

2. Ministry of Health and Department of Census and Statistics. Sri Lanka Demographic and Health Survey 2006/07 Colombo. Department of Census and Statistics 2008.

3. Wilkinson R, Marmot M Editors, Social Determinants of Health. The Solid Facts 2nd Edition Copenhagen. World Health Organization. 2013.

4. World Health Organization. Guidelines on optimal feeding of low birth-weight infants in low- and middle-income 
countries. Geneva: World Health Organization, 2011.

5. World Bank. Rising Food and Fuel Prices. Addressing the Risks to Future Generations. Human Development Network (HDN)/ Poverty Reduction and Economic Management (PREM) Network. World Bank. 2008.

6. United Nations Children Fund. The state of the World's children 2008. Child survival. New York UNICEF. 2007.

7. United Nations Children Fund. The state of the World's children 2009: Maternal and newborn health. New York: UNICEF. 2008.

8. Family Health Bureau. Annual Report on Family Health Sri Lanka 2013. Colombo Family Health Bureau. 2015.

9. Ministry of Health Sri Lanka. National Nutrition Policy of Sri Lanka. Colombo: Ministry of Health Sri Lanka. 2010.

10. Harding JE, De Boo HA. The developmental origins of adult disease (Barker) hypothesis: An invited review. Australian and New Zealand Journal of Obstetrics and Gynaecology 2006; 46:414. https://doi.org/10.1111/j.1479828X.2006. 00506.x

PMid: 16441686

11. Ohlsson A, Shah PS. Determinants and Prevention of Low Birth Weight: A Synopsis of the Evidence in IHE Report. Alberta: Institute of Health Economics. 2008.

12. United Nations Children Fund. Reduction of Low Birth Weight: A South Asia Priority. UNICEF Regional office of South Asia. 2002.

13. United Nations Children Fund. Malnutrition. UNICEF Sri Lanka Website. 2006.

14. Kramer MS. Determinants of low birth weight. Methodical assessment and a meta-analysis. Bulletin of the World Health Organisation 1987; 65(5):663-737.
PMid: 3322602 PMCid: PMC2491072

15. Family Health Bureau. Strategies to promote optimal fetal growth and minimize the prevalence of low birth weight in Sri Lanka: health sector response. Colombo: Family Health Bureau. 2013.

16. Gillespie S. Improving adolescent and maternal nutrition. An overview of benefits and options. New York UNICEF. UNICEF staff working papers: Nutrition S97-002. 1997.

17. Nordenfelt L, Liss P. Dimensions of Health and Health Promotion. New York Rodopi B.V. 2003. p. 237.

18. Abeysena C, Jaywardena P, Seneviratne R. Effect on physical activity and psychosocial stress on low birth weight: A cohort study. Journal of Obstetrics and Gynaecology Research 2002b; 36(2): 290303.

19. Wijaywardana R, Hemantha RG, Herath P. Low birth weight: The case in Thalawa and Thambuthegama Health Regions. In: Rajarata University of Sri Lanka (RUSL) Research Symposium. RUSL, 2010.

20. United Nations Children Fund (UNICEF), World Health Organization. Low birth weight: Country, regional and global estimates. New York: UNICEF. 2004.

21. Elizabeth NL, Christopher OG, Patrick K. Determining an anthropometric surrogate measure for identifying low birth weight babies in Uganda: a hospital-based cross sectional study. Bio Med Central Pediatrics 2013; 13:54. https://doi.org/10.1186/1471-2431-13-54

22. Anuranga C, Wickramasinghe R, RannanEliya RP, Hossain SMM, Abeykoon ATPL. Trends, inequalities and determinants of low birth weight in Sri Lanka. Ceylon Medical Journal 2012; 57(2): 61-9. https://doi.org/10.4038/cmj.v57i2.4429 PMid: 22772783 